\title{
Schools and Skills of Critical Thinking for Urban Design
}

\begin{abstract}
This paper explores possible ways in which urban design can engage with critical thinking and critical theory. After a brief explanation of the terms, with particular attention to the Frankfurt School of thought, it provides various answers to the question as to whether urban design is critical or not. One categorisation applied to planning critical theory is then used to explain the potential for employing critical theories in urban design. Critical thinking skills are then argued to be helpful for enriching the literature of urban design in order to achieve better practice. The conclusion is that urban design can benefit from critical creativity, that is an embodiment of critical thinking within the limits imposed onto creativity. In this paper, the ways in which urban design can engage with both critical theory and with critical thinking are explored in order to achieve better critical creativity in the field.
\end{abstract}

Key words:

Urban design theory, critical creativity, critical theory 


\section{Introduction}

What does critical thinking mean in urban design? Does urban design enable such thinking? How can designers and academics apply critical theories and critical skills in solving urban problems? What are the key schools of critical theory and how they can help urban design? Despite the fact that critical thinking has been widely identified as a key requirement for professionals the aforementioned questions have not been discussed adequately within urban design literature. The weak engagement between urban design and critical theory has queried the use critical agenda for urban design.

This paper explores the necessity of addressing such questions and provides a basic framework for better use of critical thinking principles in urban design. In so doing, the paper revisits the philosophical arguments around critical theories in order to clarify their potential for urban design. The argument is presented in three parts; after clarifying the theoretical definitions, part one hypothetically explores the relationship between urban design and critical theories; part two investigates the school of critical theory for urban design; and part three offers a set of critical thinking skills for urban design.

\section{What is a critical concept?}

The term "critical" is widely used in many fields and in day-to-day conversations, albeit with various meanings. Two meanings of the term given in the Oxford Dictionary are a) expressing adverse or disapproving comments or judgements $b$ ) expressing or involving an analysis of the merits and faults of a work of literature, music, or art. From these definitions analysis and negative commentary appear to be associated with critical thinking. This reflects the origin of the term that goes back to mid-16th century (in the sense 'relating to the crisis of a disease'): from later Latin criticus (Oxford Dictionary of English 2010). Critical thinking, however, in many references means systematic and objective evaluation of an issue in order to reach a judgment (see Brink-Budgen 2010; Cohen 2015; Cottrell 2011).

Like many other concepts, the term critique carries certain connotations that have been gradually added to the term. The seminal book of a German philosopher, Immanuel Kant called Critique of Pure Reason (1781) is in fact the key text that developed the concept of critical thinking. Kant aimed to use critique in order to make a rational philosophy entirely based on reason (Kant 2009). Inspired by this book, Dictionary of Critical Theory defines critical concepts as sets of concepts "whose reach is always and necessarily greater than their grasp" (Buchanan 2010, 101). This definition explains how critical thinking goes beyond set boundaries. This ability seems to be the nature of critical thinking.

Kant's philosophy has inspired many successors. In particular, Max Horkheimer, one of the founders of the Frankfurt School elaborated on Kant's Critique of Pure Reason in his PhD. He stated that "Kant understood that behind the discrepancy between fact and theory... there lies a deeper unity, namely, the general subjectivity upon which individual knowledge depends" (Horkheimer 1982, 203). It was he who first coined the term critical theory. Adding the word theory was not arbitrary. In fact, critical thinking in the Frankfurt School turned into what we now recognise as critical theory in the sense that it started theoretically to address social issues and systematically to employ critical concepts (Jay 1996). Key characteristics of critical theories among the circle of intellectuals who joined Horkheimer's school are summarised in the following: 
The extent of change suggested by critical theory suggests is often dramatic. Therefore, it is perceived to be radical. In many instances, critical theorists challenged perceived wisdom, in the pursuit of revolutionary change.

Another characteristic of critical theory is the fact that the key thinkers of this movement were affected by Karl Marx's philosophy. In particular, his concepts of alienation and the interpretation of events as social productions (Marx 2011). Despite the fact that not all of the members of the Frankfurt School could be categorised as Marxist, they were highly influenced by his philosophy. This resulted in seeing social identities as being defined by working and living environments. In addition, Marx's analysis of history (Marx et al. 1970) aided this circle of intellectuals in their conceptualisation of social issues, such as wars, poverty and exploitation, as the direct consequences of the class struggle and of the ways in which the production of wealth has formed society. Along with Marxism, Freud's psychoanalytic approach enabled some members of this school to link a socio-historical dimension to personal feelings (Jeffries 2016; Bottomore 2002).

The boundaries between disciplines were challenged by critical theory stimulating the necessity for interdisciplinarity, which has been encouraged by the nature of critical thinking as it aspires to go beyond any set of thinking frameworks and firm understanding of phenomena (Arato and Gebhardt 1982). For example, many influential works of the members of the Frankfurt School marry pairs of apparently unrelated areas such as psychology and politics (Fromm 2011; 1991; 2001), aesthetics and industrialisation (Adorno 2007; Adorno and Bernstein 2001) literature and urbanism (Benjamin 2016; 1986). Critical theory is interdisciplinary and it challenges the set boundaries between various areas of human knowledge. This means that critical thinking, as Adorno stated, inevitably engages with critiquing societies from various perspectives (Benzer 2011).

The various works by the Frankfurt School often raise awareness as to why the topics of their studies are important, or what is at stake in relation to any given topic. Appreciating and understanding of why a particular topic is considered attention-worthy is an important characteristic of critical theory in any given circumstance. This approach directly resulted in its theories being sensitive to their local context, time and space. The importance of this approach can be illustrated in opposition to rationalism and positivism both of which, view the subject of their study in abstract. Such abstract theorising dominated the discourse in many academic circles (in particular the Vienna Circle of philosophy) during the period when the Frankfurt School of critical thinking was formed. "Critical theory would treat facts less as isolated depictions of reality than as crystallized historical products of social action. The aim was to understand a fact within the value laden context wherein it assumes meaning" (Bronner 2011, 25). The actual socio-political context in which the critical works of the Frankfurt School emerged had a profound effect on the content of their theories. On one hand, in the East, the Bolsheviks were making dramatic changes in society. On the other hand, in Germany, a series of events followed by the First World War resulted in the Great Depression and an authoritarian government coming to power. In this circumstance, many intellectuals were motivated by the desire to effect change. Marx, again, inspired them in his call for social change: "The philosophers were only interested in interpreting the world in various ways. The point, however, is to change it" (Marx et al. 1970). In this respect, the Frankfurt School aimed to couple theory and practice, or as they preferred to express it, in praxis (Jay 1996). Abstract theory, without direct implications for society, did not appear to be of interest for the members of this movement.

In a socio-historical context, the focal point of the majority of their works was in fact critiquing modernism and the modern way of life, asking why the promises of the Enlightenment resulted in such a miserable condition for humanity. 
Critical theories and critical thinking since the Frankfurt School have resulted in the development of various circles and have benefited many disciplines. Being interdisciplinary, paying attention to contexts and studying socially-produced identities are all able to inspire urban design thinking. But first it should be clarified whether or not urban design has the capacity systematically to incorporate such thinking.

\section{Is urban design critical?}

Urban design, like almost all other disciplines, has benefited from critical theories directly and indirectly. It is important to highlight here that urban design literature consists of a diversity of texts. Nevertheless, it is possible, and in fact necessary, critically to comment on mainstream urban design as a whole; albeit different theories have different level of criticality. The question in this section, however, is whether mainstream urban design as a whole is, by its nature a critical field, and whether engagement with critical thinking is random or systematic. There are different views on the answer to these questions. In what follows, three such options are elaborated upon.

\section{First answer; Urban Design is Not Critical}

Urban design, as a field, has been condemned for various reasons in many texts (Inam 2013; Madanipour 2014; Cuthbert 2005; Gunder 2011; Banerjee 2013; Dovey 2016). Some authors suggest that urban design is not, and cannot be, critical. One of the leitmotivs of these criticisms is that urban design follows fixed models (Marcus and Francis 2003). Such a criticism indicates that urban design texts and projects advocate a certain urban form without fully understanding the urban problems involved. Urban design of this sort aims to replicate the forms of medieval cities: walkable, mixeduse, having a strong centre (Tibbalds 2000; Cowan 2002). When designing projects for big cities, mainstream urban design is expected uniformly to pedestrianize commercial streets regardless of the context. If following these fixed models were always to be the case, then urban design thinking would be bound to certain shapes which cannot go beyond this solid framework. This would make urban design thinking a non-critical practice, incapable of critical thinking.

Another argument which indicates that urban design is not critical is that "urban design, as an independent field, is largely a creation and product of neoliberalism, because it effectively mirrors its values of reification and façade, the superficial, the surface, in the commodification of the built environment" (Gunder 2011). This would mean that urban design acts merely as an instrument of global capitalism and neoliberalism. If this were the case, then urban design could not go in any other direction except to serve neoliberal powers. Consequently, urban design would not be capable of being critical. Following on from this argument, when topics such as social justice, emancipatory design and gender, are discussed under the titles of urban design, they cannot act otherwise than required by neoliberal forces.

Urban design has also been condemned for its focus on physical design or big-architecture without necessary socio-political understanding (Gunder 2011; Inam 2013; Cuthbert 2007). This feature can be identified both within the practice and the theory of urban design. The core references of urban design do not reflect critical theories (Foroughmand Araabi 2016). Even 10 years after Cuthbert's persuasive call for a move towards critical urban design (Cuthbert 2007a), critical thinking is underdeveloped. Arguably, topics such as environmentalism are absorbed only after they have been emptied of their original critical promise and turned into greenwashing (Parr 2009).

The final argument in favour of the first answer is that urban design is ultimately about the creation of new environments, whereas critical thinking is about making rational judgments and evaluating the 
consequences of existing processes. Creating a new form and critiquing existing processes are seemingly disparate endeavours. Therefore, one can argue that urban design cannot have a critical nature as long as it is merely concerned with design. Perhaps this is why Cuthbert defines urban design as the social formation of urban environments and urban meanings (Cuthbert 2007a, 2016).

\section{Answer two; Urban Design is necessarily critical}

The second possible answer to the question of whether urban is critical or not, is that urban design by its very nature is a critical field. Contracting the first answer, this answer claims that without critical thinking urban design is meaningless. Some arguments in favour of urban design as a critical field are as follows.

Urban design relies on critical concepts. Therefore it is critical. Earlier, it was explained that concepts "whose reach are greater than their grasp" are critical (Buchanan 2010, 101). This means that such concepts, for example space and society, cannot be understood through pure experience. Critical concepts can only be described when critical thinking is in operation ${ }^{1}$. Therefore, urban designers, in principle, must be aware of the fact that concepts they are dealing with go beyond any perceptual and set representation. Consequently, when designing a small section of the space for a small section of society, the ability to go beyond those boundaries is necessary in order to be able to evaluate their design. Many professionals are well aware of this point (Carmona et al. 2003; Banerjee 2013, 2011; Blllingham 2004). Thus, critical concepts are crucial for locating and making sense of any design that aims to purposefully understand the relevant context and make a change. This argument indicates that meaningful urban design is necessarily critical in its nature, because of its relation to concepts such as space and society.

Another reason supporting the view that urban design is critical follows on from the fact that urban design deals with wicked problems (Carmona 2014; Lang 2005, 205; Verma 2011). Wicked problems have no definite formulation. There is no stopping point for them. There is no well-defined solution for them and they move from one location or section to another (Skaburskis 2008; Rittel and Webber 1973). These are also characteristics of urban problems. This shows the necessity for critical thinking as it enables one to go beyond set frameworks and boundaries in order to make proper evaluations and judgments. Critical thinking endorses constant assessment of the problems in hand necessary for dealing with wicked problems that are dynamic, thus hard to grasp (Foroughmand Araabi 2017). This argument could be followed by the fact that even though many urban design projects were not identified as being critical, the very nature of their thinking resembles the characteristics implicit in critical thinking.

Arguments in favour of the second answer do not seem convincing to many scholars. In addition, its acceptance depends highly on the varying ways in which urban design is understood. Alternatively, some scholars suggest that alteration in mainstream urban design is necessary in order to make it critical (see Chase, Crawford, and Kaliski 2008; Carmona 2014b; Inam 2013).

Third answer; A middle way?

There may be an intermediate answer, as urban design is critical but not in all situations. One cannot expect urban design to bypass neoliberal regulations, nor can planning or any other field. In addition, fields that are bound to urbanisation and economic development are harder to be visualised as highly critical (Lahiji 2016).

\footnotetext{
${ }^{1}$ This echoes Kant's (2009) classification of human knowledge.
} 
Although not many scholars discuss this approach specifically, a group of urban design publications follows this in response to the question. Bentley (1999) states that urban designers inevitably work in a capitalist context, within neoliberal forces. Nevertheless, their designs can be aimed more directly at empowering people. Designers have a capacity, however restricted, to influence the ways in which any given project contributes to the public good or to how the lower classes benefit by the design. This suggests, in line with the idea underlining The Insurgent Architect at Work (Harvey 2006), that urban design can be highly critical in its thinking, however restricted its action. In this condition, urban designers are required to establish critical responses to bigger processes and use their capacity in whatever limited opportunities may arise.

It needs to be noted that many places that are examples of good urban design were created long before the emergence of neoliberal society. This illustrates the possibility of non-capitalist urban design. However, this possibility relies on assuming that neoliberal forces have not played an entirely dominant role in the world. Urban design also came to particular attention in the Soviet Union(Hatherley 2015; Lang 2005); as another example of the possibility of its usage in a nonneoliberal economy. Even though these examples are the results of processes that are not currently mainstream, they refute the claim that urban design must necessarily be in the hands of neoliberalism.

The answer to whether urban design is critical or not varies depending on definitions of the terms. Nevertheless, the arguments in this section describe the ways in which urban design is perceived to interface with critical thinking.

The next section examines the main schools of critical theory in relation to urban design. It is followed by the introduction of critical thinking skills to urban design.

\section{Schools of critical thinking and urban design}

Critical theories are systematic embodiments of critical thinking. When such theories gather round a set of beliefs and principles, they constitute a school of thought, as was the case in the Frankfurt School. To date, there has been no study identifying schools of critical urban design. In planning studies Yiftachel (1989) proposed three types of theory; rational, communicative and critical. Critical planning theory is defined as being concerned with what constitutes 'good planning' (Yiftachel 1989). This is in line with identifying critical propositions as a necessary ingredient of rational judgment (Kant 2009). More recently, Gunder suggested four categories of critical planning theory; Structuralist Political Economy Interrogation; Liberal Pragmatic Interrogation; Poststructural Interrogation; and Contemporary Neoliberal Interrogation (Gunder 2015). Considering the fact that urban design literature has engaged less with critical arguments compared to planning, this categorisation, whilst requiring adjustments, is applicable to urban design.

Such categorisation can only be applied to urban design when urban design is considered to be critical. The three answers in the previous section are therefore offered as a prerequisite for the following argument. To a considerable extent, the second and third answers enable better engagement between urban design and schools of critical theory.

The categories offered here are borrowed and adjusted from planning (Gunder 2015). Nevertheless, the critical literature of urban design can be reflected on this categorisation, which would highlight what critical theories have to offer to urban design.

Some scholars consider only one category to be valid. This is specifically the case for those who consider Marxist political economy as the only valid framework for understanding the socio-political 
forces behind the formation of urban problems. Nonetheless, this paper aims to identify all dominant schools of thought in which various forms of critical thinking are consolidated.

\section{Structuralist Political Economy Interrogation}

Structuralist political economy is a category of critical theory deeply inspired by Marx. In urban studies, this became a key school of thought when Marxist thinkers began to study the concept of space, adding a spatial dimension to political economy (Castells 1977; Lefebvre 2011; Harvey 1989). Structuralist political economy is attractive to scholars because it provides an apparently rigorous epistemological rationalisation whereby explanatory roots of the structured and structuring social relations are identified (Soja 2011, 53). Critical urban theory is one current version of structuralist political economy which Brenner describes as a term referring to 'leftie' urban thinkers:

"Rather than affirming the current condition of cities... critical urban theory emphasizes the politically and ideologically mediated, socially contested and therefore malleable character of urban space-that is, its continual (re)construction as a site, medium and outcome of historically specific relations of social power" (Brenner 2009).

This particular school of thinking is presented in the journal City published by Taylor and Francis ${ }^{2}$. Critical urban theory studies the deep involvement of cities with capitalism. It asks how urbanism without capitalism and how capitalism without urbanism would be possible. This school of critical theory can be related to urban design if urban designers act as "associated producers of space" (Goonewardena 2011).

In urban design literature, Cuthbert is considered to be the dominant voice of structuralist political economy (Cuthbert 2007a; 2003; 2005). However, long before this, King had raised the question as to what urban design and emancipatory design mean in a capitalist society (King 1996 \& 1988). Unlike many other urban design texts, works from the perspective of structuralist political economy do not directly lead design practice, contrasting Marx's call for making change. Despite the fact that this approach is helpful in understanding cities, it seems that when it comes to making suggestions, it becomes less distinguishable from mainstream urban design. For example:

"There is no reason why urban design should not be vibrant and real, that it can be appropriately theorized, that urban form can create new experiences and spaces, and even on occasion that the collective good will triumph over economic imperatives" (Cuthbert 2016).

In terms of the content, texts belonging to this category mainly critique the current condition of cities as privatising public spaces and assets (Low and Smith 2006). They also criticise mainstream urban design for not being underpinned by substantial theory capable of acknowledging the socio-political forces behind urban meaning (Cuthbert 2007b).

\section{Pragmatic Criticality}

Pragmatist critically empowers theories that are focused on delivering intended outcomes and is not particularly concerned with political direction. It examines existing literature, or the direction in which the field is going on the basis of efficiency. In so doing, it requires a model or a theoretical assessment that shows the disadvantages of the existing situation and the possibilities for a better one. In making assessments of the existing situation, it provides a framework for making critical judgments.

\footnotetext{
${ }^{2}$ http://www.city-analysis.net
} 
Works in this category include a wide range of texts that are reluctant to take any political direction. Marshall's argument for assessing the changes in cities with reference to Evolution Theory (Marshall 2009); his suggestion for using scientific capacities of urban design theories (Marshall 2012); and his recent article on using cooperative artistic mechanisms for urban design (Marshall 2016); all fall into this category. Despite the fact that they have different subjects, they do not have a clear political direction but do offer new frameworks for better urban design. This is also applies to many key theories developed by key urban designers, for example, Lynch (1960) and Alexander et. al (1977).

According to this definition, technical and scientific theories fall into this type of critical tradition. Texts such as Space Syntax, criticising changes in urban form as failing to match up to social logic (Hillier 2008; Hillier and Hanson 1984); Fractal Cities, criticising urbanisation without understanding the natural complexity of settlements (Batty and Longley 1994); and the use of Big Data, criticising the management of the complex system (Batty 2013) all rely on the tradition of empiricism. This category may alternatively be entitled empirical criticism.

\section{Post-structural Interrogation}

Post-structuralism as an intellectual movement flourished in the second half of the twentieth century. The work of many thinkers amongst them Gilles Deleuze and Felix Guattari, Jean-François Lyotard, Michel Foucault and Jacques Derrida falls into this category. In addition to falling within the same social context, these philosophers show some common interests and address similar concepts in their philosophy. Their thinking by its nature is critical, insomuch as it seeks to provide a better understanding of the complexity of power as being something more than a matter of coercion or repression (Buchanan, 2008, p. 21).

The key figures of post-structuralism also believe that society should not merely be understood as the product, or the expression of, the powerful majority exercising influence over the minority. Instead, power resides in ordinary language, and in the way people organise their lives. In this context, capitalism is seen as creating the parlous condition of the world. What the Frankfurt School criticized was the big scale, authoritative and Fordist version of modernism, whereas poststructuralism considers power to be uncertain and complex and addresses a Post-Fordist version of modernization.

Kant's philosophy, Marx's history and the Frankfurt School's reading of capitalism and psychoanalysis are philosophical frameworks in the form of superstructures that supposedly explain every phenomenon. Poststructuralism moves on from such superstructures and takes into account processes that cannot be understood by such frameworks. In this, poststructuralism has similarities with pragmatism.

During the 1960s, at the same time as the emergence of the poststructuralism, urban design seminal thinkers began to criticise top-down modern urbanism for its oversimplified understanding of human beings and cities (Lang 1987). Le Corbusier's work had come to symbolise this top-down modernist approach embodying massive-scale urbanisation (Fordist). Christopher Alexander, among many others, aimed to replace this simplified understanding with a more complex model for appreciating that there are aspects of cities which can never fully be grasped or understood (Alexander 1965, 1999). This reverberates with what is discussed in many post-structuralist philosophies. A City is Not a Tree (Alexander 1965) has similarities with the concept of the rhizome ${ }^{3}$ (Deleuze and Guattari 2002). Within different scopes, both call for an acknowledgment of the unpredictable connections between

\footnotetext{
${ }^{3}$ The connections that occur between the most disparate and the most similar of objects, places and people; the strange chains of events that link people (Parr 2010, 232).
} 
seemingly-separate sections of cities or processes in the world. Nowadays, the ideas of autonomy (Aureli 2008), participatory urban design (Sendra 2015) and urban assemblage (Dovey 2010) are examples of such thinking in which, instead of top-down structured procedures, bottom-up movements enable people to participate in the creation of good public spaces and cities.

\section{Neoliberal Interrogation}

Neoliberalism is profit-oriented yet it is claimed to create significantly greater benefits for a greater number of people than any other system. The ability of neoliberal policies to produce high-quality urban developments (Künkel and Mayer 2012) and urban design projects (Chapman 2014, 1996) has been addressed in the literature. Neoliberalist economy has managed to make many high-quality (often) privately owned but publicly accessible spaces (Zukin 2010; Glaeser 2011). Nevertheless, very few scholars acknowledged the potential abilities of this approach to be critical.

Jane Jacobs's works fall into this category (Hirt and Zahm 2012). She was one of the harshest critics of the urbanisation of her time. Her criticisms became mainstream in urban design (Alexiou 2006) after a while. Even though she does not directly indicate the politics behind her ideas in The Death and Life of Great American Cities (Jacobs 1992), it is nevertheless concluded that her suggestions work better within a neoliberal discourse (Hirt and Zahm 2012). She trusts the free market and its ability to produce public good when people freely act for their individual interests. Neoliberal interrogation seems to be the main mode of governing place-making in times of austerity (Carmona, Magalhães, and Natarajan 2017). Therefore, finding critical directions in this discourse is of importance for future researches.

\section{Skills of critical thinking for urban design}

Schools of critical theory consolidate various trends in the history of critical thinking. However, it is critical thinking skills which enable critical judgments to be made in practice. Through using critical thinking skills, urban design can enrich the critical body of the literature. Gunder, following Cuthbert (2007a), concludes that urban design sits more comfortably within urban planning because of planning's critical research agenda and its educationally-focused engagement with a wide range of socio-environmental issues (Gunder 2011). The problem with this suggestion is that merely subsuming urban design under urban planning or social sciences does not per se alter its content. Alternatively, operationalizing critical skills can create critical research, critical knowledge and critical pedagogy.

Having a clearer understanding of the skills implicit in critical thinking is helpful for a wide range of urban design activities. Many references on critical thinking skills describe them as a process with various steps, from understanding the studied phenomenon, to making judgments about it. Critical judgments therefore contribute to a better understanding of, thus leading to facilitating the decisionmaking process (Cottrell 2011; Cohen 2015; Brink-Budgen 2010). Urban designers constantly make decisions that may or may not be critical. Returning to Yiftachel's (1989) definition of critical planning theory, the key element is making judgments about what is a good design. It is important first of all to make assessments according to the client's requirements. This judgment is probably not highly critical. If the designers explore beyond a pre-defined framework, this can be seen as a critical action. One example could be the recognition as to who will receive benefits and who will lose opportunities because of a development, in ways that are not considered in the design brief and in the literature. Skills involved in critical thinking can enable such considerations to be taken into account. 
Many studies have explored the relationship between certain techniques and critical thinking. Barry Richmond, a system thinking theorist, suggests a set of critical thinking techniques suitable for a systematic approach (Richmond 1993). He introduces seven key critical thinking skills. The following descriptions of skills of critical thinking apply Richmond's suggestions to urban design and identifies examples of where such thinking is currently being used in the field. This could be a first step to more systematically applying critical skills to urban design.

- Dynamic thinking: "is the ability to see and deduce behaviour patterns rather than focusing on, and seeking to predict, events" (Richmond 1993). Dynamic thinking in urban design rejects environmental determinism (Lang 1994), as. Urban problems emerge as the result of ongoing processes unfolding certain patterns through time. Therefore, dynamic thinking necessitates an understanding of the specific characteristics of each problem and aims to create a flexible outcome through malleable tools.

- Closed-loop thinking: requires seeing any phenomenon as being the result of a set of interdependent processes. Closed-loop thinking relies on circular cause-effect relations. In urban design, an example is the relation between diversity and density, a very complex relation (Dovey and Pafka 2014) where diversity and density can each create (or contribute towards the emergence of) the other. Close-loop thinking appreciates the uniqueness of each case. Yet it does not deny the possibility of studying the reasons behind any given phenomenon. The first two skills are close to what Schon conceptualised as features of a reflective practitioner (Schon 1984).

- Generic thinking: Many concepts are understood in relation to specific meanings. For example, modern architecture in urban design literature has been criticised for not providing diversity, human-scale environments or sense of place (Jacobs 1992; Tibbalds 2000; Lynch 1960; Lang 2005). Generic thinking requires going beyond such connotations and revisiting the phenomena with a fresh mind. It is argued that urban design suggests a certain urban form, walkable, pre-modern-looking and mixed-use (Llewellyn 2000; Tibbalds 2000), prior to fully understanding the problem in hand. If this were true, then generic thinking about concepts such as vitality, sense of place, walkability (just to mention a few) would be essential for the field. Otherwise, a set of orthodoxies would dominate the creation of urban design practice.

- Structural thinking: is to think in "terms of units and measures, or dimensions" (Richmond 1993) ${ }^{4}$. Urban problems can easily be interpreted antithetically. For example, whilst for Harvey urban life is on the verge of a big crises (Harvey 1989, 2013, 2014), Gleaser celebrates the urban condition for its outstanding successes (Glaeser 2011). Thinking in terms of specific measures would clarify what exactly indicates the goodness/badness of urban life. Nevertheless, structural thinking should be in balance with dynamic and closed-loop thinking. In the literature, there are many outstanding examples of systematically measuring qualities of urban design (Ewing and Handy 2009; Clifton et al. 2008).

- Operational thinking: is finding out how things really work, not how they work in theory. For example, the literature of urban design suggests that eyes on streets (Jacobs 1992) provides safety. But no study should be blinded from seeing the reality merely because of what a theory suggests. Operational thinking means theory must aim to remove the gap between theory and reality.

- Continuum thinking: asks what happens after solving problems; what are the by-products caused by problem-solving endeavours? One example is massive housing projects for fulfilling

\footnotetext{
${ }^{4}$ Structural thinking here, as a technique, must not be confused with structuralism.
} 
housing needs. Such projects may successfully achieve the objectives, but they can produce more problems, as the infamous 1960's urban expansion showed.

- Scientific thinking: means having a sound theoretical understanding in mind when dealing with a problem. Even though it is argued that urban design is not scientific, the importance of theory has been acknowledged throughout the literature (Dovey and Pafka 2015; Lynch 1981; Sternberg 2000; Biddulph 2012). Without rigorous theory, urban design would be in danger of simply repeating the mistakes of the past, and would not learn from failures or successes. Urban design without sound theory can also be hijacked by existing forces, resulting, for example in a giant three-dimensional fashion show of capitalist competitiveness. Scientific thinking in this meaning has long been seen as important to the field.

A balance of the seven skills is needed for comprehensive critical work. Nevertheless, applying all seven skills cannot always guarantee a successful outcome. Critical thinking does not lend itself to being rigidly formulated. This is neither a comprehensive list of necessary skills nor does it precisely define the process of critical thinking. It only aims to illustrate the possibility of using critical thinking techniques to encourage critical analyses at the various stages in urban design.

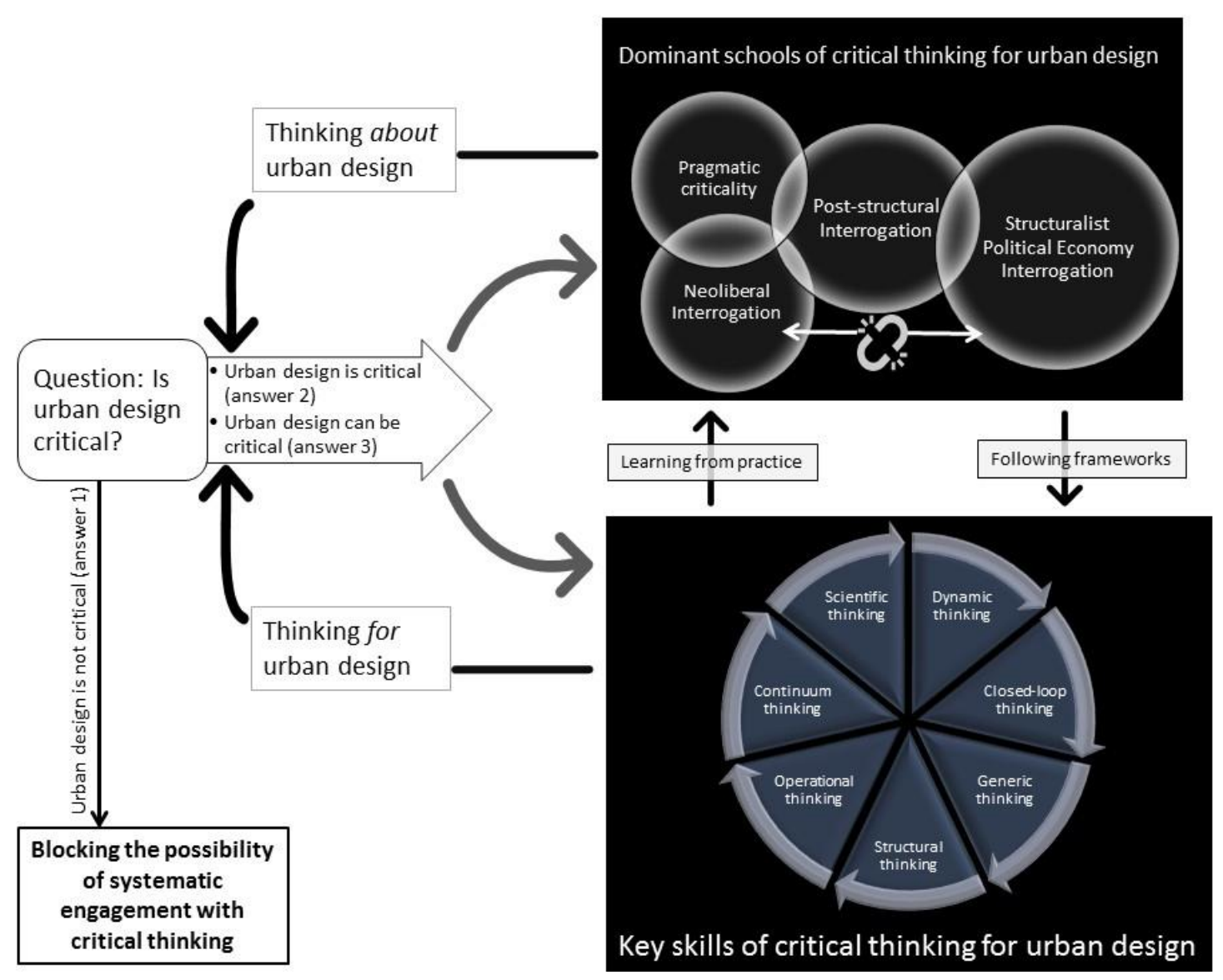

Figure 1; if critical thinking is possible (answers one and three in this paper) then the schools of critical theory and the skills of critical thinking can be represented in the above conceptual diagram

Figure 1 conceptually summarizes the import of this paper. If the answer to the first question (whether or not urban design is critical) offers the possibility of critical thinking, then the schools and skills of critical thinking are considered to be useful. Otherwise, urban design's engagement with critical thinking is random. The aforementioned schools of critical theory have their own relationship with one another. Structuralist political economy interrogation conflicts with both neoliberal 
interrogation and pragmatic criticality. This has occurred because the structuralist political economy's frameworks are formed by the inflexible idea of power and political structures, whereas pragmatic criticality and neoliberal interrogation define their own frameworks differently in each individual case. Post-structural interrogation overlaps with other schools, insomuch as it employs flexible frameworks that could be compatible with the political framework integral to Structuralist political economy and the flexible frameworks of the other two schools.

Moving from schools of critical theory to applying the key skills of critical thinking occurs when an urban designer applies any given framework to a real case. The opposite movement, from skills to schools, can happen when critical urban design theory is informed by practice.

Considering the question (whether urban design is critical or not) from the perspective of the schools of critical thinking, replicates what Biddulph (2012) conceptualises as thinking about urban design; that is constructing urban design theories from the perspective of social science. Following on from this perspective, returning to the first question from the perspective of operational skills replicates thinking for urban design; that is using methods for engaging critically with urban problems in practice (Biddulph 2012).

Despite the fact that critical thinking brings attention to previously unexplored issues. It is also expected that putting skills of critical thinking into operation will highlight certain subjects of study. As dynamic thinking and generic thinking invite exploration of greater areas, a more comprehensive conception of space is expected to become an issue. The relationships between space, society and economy will be a leitmotiv of critical urban design practice. Continuum thinking draws attention in urban developments to minorities and marginalised group such as gender, disablement, race, class and immigrant. Operational thinking enables urban designers to take into account the complexities of nature and of urban ecology, which cannot be fully dealt with by using standards and frameworks. Scientific and structural thinking challenge interdisciplinary, paving the way for making judgments about urban design projects from different perspectives. Above all, using critical skills in urban design would enable practitioners to deal with future problems critically. This approach strongly connects thinking for and thinking about urban design (Biddulph 2012).

Despite the value of these critical skills, they do not obviate the need for a deep understanding of their theoretical underpinning. Such skills cannot replace an in-depth understanding of the various schools, but they aim to complement them. At the same time, no school can by itself adequately inform the practice of urban design. Both schools and skills are needed in order to generate critical content for urban design.

\section{Conclusion: Towards Critical Creativity}

The application of critical thinking in general and critical theories in particular would be beneficial for urban designers by putting critical thinking at the heart of design. This may be considered to be a challenging suggestion insomuch as critical thinking aspires to go beyond set frameworks and boundaries, and is more interested in analysing, questioning and making new judgments rather than in focusing on producing new urban forms. How this would be coupled with a design process is one of the challenges when a stronger connection between critical thinking and urban design is at stake. It unmasks tensions between "criticality" and "creativity" that are deeply rooted in urban design traditions. Contrasts between descriptive versus prescriptive theories (Lynch 1981; Moudon 1992) and urban versus design (Madanipour 1996) are examples of those tensions. 
As creativity without critical thinking can easily be hijacked by noncritical forces and powers, a purely creative approach is inadequate to serve urban design thinking. On the other hand, pure criticality alone is insufficient. Therefore, what urban design needs is critical creativity; criticality (including assessing, questioning and making judgments) and creativity (including designing and making new forms) interwoven. Thus, there would be a dynamic relationship between criticality and creativity. Creativity would not then merely be making new forms but also embodying new critical thinking. Equally, a critical approach would aim to make judgments that ultimately contribute to better design output and better life experiences rather than focusing on negative aspects.

Critical creativity, which is not to be confused by any previous use of this term ${ }^{5}$, here offers an approach to future research and to those practices concerned with keeping urban design linked to critical thinking. Despite the fact that this approach indicates good design, the test of time remains paramount. In this regard, as with any other theoretical framework, what happens in reality, in this case in cities, is the final validation process.

This paper offers a particular understanding of the schools of critical theories, aiming to invite the application of critical thinking to urban design. However, there are many other ways of understanding critical theory and of applying critical thinking to urban design. Dovey in his recent book aims "to inspire critical thinking about urban design" through offering an open-thinking conceptual toolbox (Dovey 2016). The contribution of this paper should be seen in relation to a greater argument about how critically to think about urban design and how critically to implement urban design.

Key characteristics of critical thinking and the necessity for its use in urban design were addressed in this paper. Mainstream modes of urban design currently are not critical, but there is potential for better employing critical skills in urban design. This could only be actualised by professionals who are interested in going beyond existing processes; beyond the design frameworks and manuals. Universities have a pivotal role in teaching critical thinking to the next generation of professionals. This paper aims to make a contribution towards fostering this movement.

\section{References}

Adorno, Theodor W., ed. 2007. Aesthetics and Politics. Radical Thinkers 13. London New York, NY: Verso.

Adorno, Theodor W., and J. M. Bernstein. 2001. The Culture Industry: Selected Essays on Mass Culture. Routledge Classics. London; New York: Routledge.

Alexander, Christopher. 1965. 'A City Is Not a Tree'. Architectural Form 172. 1999. 'The Origins of Pattern Theory; the Future of the Theory, and the Generation of Living World'. IEEE Software 16 (5): 71-82.

Alexander, Christopher, Sara Ishikawa, and Murray Silverstein. 1977. A Pattern Language: Towns, Buildings, Construction. New York: Oxford University Press.

Alexiou, Alice Sparberg. 2006. Jane Jacobs: Urban Visionary. New Brunswick, N.J: Rutgers University Press.

Arato, Andrew, and Eike Gebhardt, eds. 1982. The Essential Frankfurt School Reader. New York: Continuum.

Aureli, Pier Vittorio. 2008. The Project of Autonomy: Politics and Architecture within and

\footnotetext{
${ }^{5}$ https://criticalcreativity.org/
} 
against Capitalism. 1. paperback ed. FORuM Project. New York, NY: Princeton Architectural Press.

Banerjee, Tridib. 2011. 'Response to "Commentary: Is Urban Design Still Urban Planning?": Whither Urban Design? Inside or Outside Planning?' Journal of Planning Education and Research 31 (2): 208. . 2013. Urban Design. 1st edition. New York: Routledge.

Batty, Michael. 2013. The New Science of Cities. Cambridge, Massachusetts: MIT Press. Batty, Michael, and Paul Longley. 1994. Fractal Cities: A Geometry of Form and Function. London: Acad. Press.

Benjamin, Walter. 1986. Reflections: Essays, Aphorisms, Autobiographical Writing. New York: Schocken Books.

2016. The Storyteller: Tales out of Loneliness. First [edition]. Brooklyn, NY: Verso. Bentley, Ian. 1999. Urban Transformations, Power, People and Urban Design. London: Routledge.

Benzer, M. 2011. 'Social Critique in the Totally Socialized Society'. Philosophy \& Social Criticism 37 (5): 575-603. doi:10.1177/0191453710393317.

Biddulph, Mike. 2012. 'The Problem with Thinking about or for Urban Design',. Journal of Urban Design.

BIllingham, John. 2004. 'The Evolution of American Urban Design: A Chronological Anthology; Book Review'. Urban Design Quarterly.

Bottomore, Thomas Burton. 2002. The Frankfurt School and Its Critics. Rev. ed. Key Sociologists. London: Routledge.

Brenner, Neil. 2009. 'What Is Critical Urban Theory?' City 13 (2-3): 198-207. doi:10.1080/13604810902996466.

Brink-Budgen, Roy Van den. 2010. Critical Thinking for Students: Learn the Skills of Analysing, Evaluating and Producing Arguments. Oxford: How To Books.

Bronner, Stephen Eric. 2011. Critical Theory: A Very Short Introduction. New York, N.Y: Oxford University Press.

Buchanan, Ian. 2008. Deleuze and Guattari's Anti-Oedipus: A Reader's Guide. Continuum Reader's Guides. London; New York: Continuum.

- 2010. A Dictionary of Critical Theory. 1st ed. Oxford Paperback Reference. Oxford: Oxford University Press.

Carmona, Matthew. 2014. 'The Place-Shaping Continuum: A Theory of Urban Design Process'. Journal of Urban Design 19 (1): 2-36. doi:10.1080/13574809.2013.854695.

Carmona, Matthew, Tim Heath, Steve Tiesdell, and Taner Oc. 2003. Public Places, Urban Spaces: The Dimensions of Urban Design. Routledge.

Carmona, Matthew, Claudio de Magalhães, and Lucy Natarajan. 2017. Design Governance: The CABE Experiment. New York, NY: Routledge.

Castells, Manuel. 1977. The Urban Question, A Marxist Approach,. Vol. first. Edward Arnold.

Chapman, David, ed. 1996. Creating Neighbourhoods and Places in the Built Environment. 1. ed. The Built Environment Series of Textbooks. London: Spon.

2014. 'Neoliberal Urbanism and Its Contestations, Crossing Theoretical

Boundaries'. Journal of Urban Design 19 (4): 567-68. doi:10.1080/13574809.2014.924287.

Chase, John, Margaret Crawford, and John Kaliski, eds. 2008. Everyday Urbanism.

Expanded ed. New York: Monacelli Press.

Clifton, Kelly, Reid Ewing, Gerrit-Jan Knaap, and Yan Song. 2008. 'Quantitative Analysis of Urban Form: A Multidisciplinary Review'. Journal of Urbanism: International Research on Placemaking and Urban Sustainability 1 (1): 17-45. doi:10.1080/17549170801903496. Cohen, Martin. 2015. Critical Thinking Skills for Dummies. Chichester: John Wiley \& Sons, 
Ltd.

Cottrell, Stella. 2011. Critical Thinking Skills: Developing Effective Analysis and Argument. 2. ed. Palgrave Study Skills. Basingstoke: Palgrave Macmillan.

Cowan, Robert. 2002. Urban Design Guidance: Urban Design Frameworks, Development

Briefs and Master Plans. ICE Publishing.

Cuthbert, Alexander. 2003. Designing Cities: Critical Readings in Urban Design. Oxford: John Wiley \& Sons.

- 2005. 'A Debate from down-under: Spatial Political Economy and Urban Design'. URBAN DESIGN International 10: 223-34. . 2007a. The Form of Cities: Political Economy and Urban Design.

- 2007b. 'Urban Design: Requiem for an Era - Review and Critique of the Last 50 Years'. URBAN DESIGN International 12: 177-223.

—. 2016. 'No More Michelangelo's - No More Art'. Journal of Urban Design 21 (4): 429-31. doi:10.1080/13574809.2016.1202676.

Deleuze, Gilles, and Felix Guattari. 2002. A Thousand Plateaus Capitalism and

Schizophrenia. Athlone Contemporary European Thinkers. London: Continuum.

Dovey, Kim. 2010. Becoming Places: Urbanism/architecture/identity/power. London; New York: Routledge.

2016. Urban Design Thinking: A Conceptual Toolkit. London; New York:

Bloomsbury Academic, An imprint of Bloomsbury Publishing Plc.

Dovey, Kim, and Elek Pafka. 2014. 'The Urban Density Assemblage: Modelling Multiple

Measures'. URBAN DESIGN International 19 (1): 66-76. doi:10.1057/udi.2013.13.

- 2015. 'The Science of Urban Design?' URBAN DESIGN International, December. doi:10.1057/udi.2015.28.

Ewing, Reid, and Susan Handy. 2009. 'Measuring the Unmeasurable: Urban Design Qualities Related to Walkability'. Journal of Urban Design 14 (1): 65-84.

doi:10.1080/13574800802451155.

Foroughmand Araabi, Hooman. 2016. 'A Typology of Urban Design Theories and Its

Application to the Shared Body of Knowledge'. URBAN DESIGN International 21 (1): 1124. doi:10.1057/udi.2015.6.

2017. 'Multiple Expectations: Assessing the Assumed Roles of Theory in Relation to Urban Design'. Journal of Urban Design 22 (5): 658-69.

doi:10.1080/13574809.2017.1298402.

Fromm, Erich. 1991. The Sane Society. London: Routledge.

http://site.ebrary.com/id/5003412.

- 2001. The Fear of Freedom. London: Routledge.

. 2011. Escape from Freedom. New York; Tokyo: Ishi Press.

Glaeser, Edward. 2011. Triumph of the City. London: Pan Books.

Goonewardena, Kanishka. 2011. 'Critical Urbanism: Space, Design, Revolution'. In

Companion to Urban Design, edited by Tridib Banerjee and Anastasia Loukaitou-Sideris, 97-108. New York: Routledge.

Gunder, Michael. 2011. 'Commentary: Is Urban Design Still Urban Planning? An

Exploration and Response'. Journal of Planning Education and Research 31 (2): 184-95. doi:10.1177/0739456X10393358.

2015. 'Critical Planning Theory'. In International Encyclopedia of the Social \&

Behavioral Sciences, 255-60. Elsevier.

http://linkinghub.elsevier.com/retrieve/pii/B9780080970868740268.

Harvey, David. 1989. The Urban Experience. Baltimore: Johns Hopkins University Press.

—. 2006. Spaces of Hope. Reprinted, Transferred to digital print. Edinburgh: Edinburgh Univ. Press. 
2013. 'Rebel Cities; from the Right to the City to the Urban Revolution'.

http://www.legimus.se/work/redirect?MedieNr=CA10533.

2014. Seventeen Contradictions and the End of Capitalism.

Hatherley, Owen. 2015. Landscapes of Communism: A History through Buildings. London:

Allen Lane.

Hillier, Bill. 2008. 'Space and Spatiality: What the Built Environment Needs from Social

Theory'. Building Research \& Information 36 (3): 216-30.

doi:10.1080/09613210801928073.

Hillier, Bill, and Julienne Hanson. 1984. The Social Logic of Space.

http://search.ebscohost.com/login.aspx ?direct=true \&scope $=$ site $\& d b=n l e b k \& d b=n l a b k \& A N=$ 711679.

Hirt, Sonia, and Diane L. Zahm, eds. 2012. The Urban Wisdom of Jane Jacobs. Planning, History and Environment Series. London; New York: Routledge.

Horkheimer, Max. 1982. Critical Theory: Selected Essays. New York: Continuum Pub. Corp. Inam, Aseem. 2013. Designing Urban Transformation. First edition. New York: Routledge. Jacobs, Jane. 1992. The Death and Life of Great American Cities. Vintage Books ed. New York: Vintage Books.

Jay, Martin. 1996. The Dialectical Imagination: A History of the Frankfurt School and the Institute of Social Research, 1923-1950. Weimar and Now 10. Berkeley: University of California Press.

Jeffries, Stuart. 2016. Grand Hotel Abyss: The Lives of the Frankfurt School. London; New York: Verso, an imprint of New Left Books.

Kant, Immanuel. 2009. Critique of Pure Reason. 15. print. The Cambridge Edition of the Works of Immanuel Kant, general ed. : Paul Guyer and Allen W. Wood[...]. Cambridge: Cambridge University Press.

King, Ross. 1988. 'Urban Design in Capitalist Society'. Environment and Planning D 6: 445-74.

1996. Emancipating Space: Geography, Architecture, and Urban Desig. The

Guilford Press; First Edition edition.

Künkel, Jenny, and Margit Mayer, eds. 2012. Neoliberal Urbanism and Its Contestations:

Crossing Theoretical Boundaries. Houndmills, Basingstoke Hampshire ; New York: Palgrave Macmillan.

Lahiji, Nadir. 2016. Can Architecture Be an Emancipatory Project?: Dialogues on the Left. Alresford: Zero books.

Lang, Jon. 1987. Creating Architectural Theory: The Role of the Behavioral Sciences in Environmental Design. New York: Van Nostrand Reinhold Co.

- 1994. Urban Design: The American Experience. Van Nostrand Reinhold,. 2005. Urban Design: A Typology of Procedures and Products. Architectural Press,.

Lefebvre, Henri. 2011. The Production of Space. Translated by Donald Nicholson-Smith.

Nachdr. Malden, Mass.: Blackwell.

Llewellyn, Davis. 2000. Urban Design Compendium. English Partnerships.

Low, Setha M., and Neil Smith, eds. 2006. The Politics of Public Space. New York:

Routledge.

Lynch, Kevin. 1960. The Image of the City. Cambridge: MIT press.

- 1981. A Theory of Good City Form. MIT Press ,.

Madanipour, Ali. 1996. Design of Urban Space, an Inquiry into a Socio-Spatial Process.

Chichester; New York: Wiley. 2014. Urban Design, Space and Society. Planning, Environment, Cities.

Basingstoke, Hampshire: Palgrave Macmillan.

Marcus, Clare Cooper, and Carolyn Francis, eds. 2003. People Places: Design Guidelines for 
Urban Open Space. 2. ed, [8. print.]. New York: Wiley.

Marshall, Stephen. 2009. Cities Design and Evolution. Abingdon, Oxon; New York, NY:

Routledge.

- 2012. 'Science, Pseudo-Science and Urban Design'. URBAN DESIGN International 17 (4): 257-71. doi:10.1057/udi.2012.22.

- 2016. 'The Kind of Art Urban Design Is'. Journal of Urban Design, February, 1-25. doi:10.1080/13574809.2015.1133226.

Marx, Karl. 2011. Economic and Philosophic Manuscripts of 1844. Blacksburg, Va.: Wilder Publications.

Marx, Karl, Friedrich Engels, C. J. Arthur, Karl Marx, and Karl Marx. 1970. The German Ideology. London: Lawrence \& Wishart.

Moudon, Anne Vernez. 1992. 'A Catholic Approach to Organizing What Urban Designers

Should Know'. Journal of Planning Literature 6 (4): 331-49.

Oxford Dictionary of English. 2010. 3rded. Oxford University Press.

http://www.oxfordreference.com/view/10.1093/acref/9780199571123.001.0001/acref-

9780199571123.

Parr, Adrian. 2009. Hijacking Sustainability. Cambridge, Mass: MIT Press.

—. 2010. The Deleuze Dictionary: 2nd Revised Edition. Edinburgh: Edinburgh

University Press.

Richmond. 1993. 'Systems Thinking: Critical Thinking Skills for the 1990s and beyond'.

System Dynamics Review 9 (2): 113-33.

Rittel, Horst W. J., and Melvin M. Webber. 1973. 'Dilemmas in a General Theory of

Planning'. Policy Sciences 4 (2): 155-69. doi:10.1007/BF01405730.

Schon, Donald. 1984. The Reflective Practitioner: How Professionals Think in Action. Basic

Books.

Sendra, Pablo. 2015. 'Rethinking Urban Public Space: Assemblage Thinking and the Uses of Disorder'. City 19 (6): 820-36. doi:10.1080/13604813.2015.1090184.

Skaburskis, Andrejs. 2008. 'The Origin of "Wicked Problems"'. Planning Theory \& Practice 9 (2): 277-80. doi:10.1080/14649350802041654.

Soja, Edward W. 2011. Postmodern Geographies: The Reassertion of Space in Critical Social Theory. Nachdr. Radical Thinkers. London: Verso.

Sternberg, Ernest. 2000. 'An Integrative Theory of Urban Design'. Journal of the American Planning Association 66 (3): 265-78.

Tibbalds, Francis. 2000. Making People Friendly Towns: Improving the Public Environment in Town and Cities. Taylor \& Francis; New edition edition.

Verma, Niraj. 2011. 'Urban Design: An Incompletely Theorized Project'. In Companion to Urban Design, edited by Tridib Banergee and Anastasia Loukaitou-Sideris, 57-70. New

York: Routledge.

Yiftacjel, O. 1989. 'Towards a New Typology of Urban Planning Theories'. Environment and Planning B: Planning and Design 16: 23-39.

Zukin, Sharon. 2010. Naked City: The Death and Life of Authentic Urban Places. Oxford; New York: Oxford University Press. 